Abstracta Iranica Abstracta Iranica

Revue bibliographique pour le domaine irano-aryen

Volume 25 | 2004

Comptes rendus des publications de 2002

\title{
Introducción al Avéstico. Madrid, Ediciones Clásicas, 2001, 140 p. (Instrumenta Studiorum. Serie : Lenguas Indoeuropeas).
}

Philip Huyse

\section{(2) OpenEdition}

Journals

Édition électronique

URL : http://journals.openedition.org/abstractairanica/4116

DOI : 10.4000/abstractairanica.4116

ISSN : 1961-960X

Éditeur :

CNRS (UMR 7528 Mondes iraniens et indiens), Éditions de l'IFRI

Édition imprimée

Date de publication : 15 mai 2004

ISSN : 0240-8910

Référence électronique

Philip Huyse, «Introducción al Avéstico. Madrid, Ediciones Clásicas, 2001, 140 p. (Instrumenta

Studiorum. Serie : Lenguas Indoeuropeas). », Abstracta Iranica [En ligne], Volume 25 | 2004, document

26, mis en ligne le 15 mars 2006, consulté le 25 septembre 2020. URL : http://

journals.openedition.org/abstractairanica/4116; DOI : https://doi.org/10.4000/abstractairanica.4116

Ce document a été généré automatiquement le 25 septembre 2020.

Tous droits réservés 


\title{
Introducción al Avéstico. Madrid, Ediciones Clásicas, 2001, 140 p. (Instrumenta Studiorum. Serie : Lenguas Indoeuropeas).
}

\author{
Philip Huyse
}

1 Alors qu'il existe plusieurs descriptions plus ou moins détaillées des langues de l'ancien et du moyen iranien, le manque de manuels et autres instruments d'apprentissage se fait parfois cruellement sentir. Dans ce contexte, les deux auteurs précisent (p. 7) que leur ouvrage a été conçu comme une introduction s'adressant tout particulièrement aux étudiants espagnols en philologie classique et études indo-européennes désireux d'apprendre une des plus anciennes langues de l'indo-européen, ce qui explique le grand nombre de références utiles au grec et au latin, à part les renvois évidents à l'indo-européen, l'indo-iranien et l'indo-aryen ancien.

2 De façon à la fois claire et concise, l'ouvrage donne un aperçu de la phonologie (pp.14-40) et de la morphologie (pro)nominale et verbale (pp.41-93) de la langue avestique, sans oublier les questions de syntaxe (pp.94-100). Si les parties grammaticales de l'ouvrage sont parfaitement appropriées à l'étude autodidacte, la lecture des textes nécessite par contre l'accompagnement par un enseignant. En effet, le choix des textes à la fin du petit volume (pp. 101-107) aurait pu être plus large et surtout accompagné de notes afin de faciliter l'étude individuelle. De même, la description des textes avestiques (p.11) est restée un peu trop générale pour un manuel. En revanche, ceux qui enseignent la langue utiliseront avec profit ce précis de grammaire avestique et on ne peut qu'encourager la rédaction de ce genre d'ouvrage pour d'autres langues, en particulier le pehlevi et le sogdien. 
INDEX

Thèmes : 2.1. Langues anciennes

\section{AUTEURS}

PHILIP HUYSE

CNRS - Paris 